N. KAPLANERIS, F. KALTENHÄUSER, G. SIRVINSKAITE, S. FAN, T. DE OLIVEIRA,

L.-C. CONRADI, L. ACKERMANN* (GEORG-AUGUST-UNIVERSITÄT GÖTTINGEN AND

GERMAN CENTER FOR CARDIOVASCULAR RESEARCH, BERLIN, GERMANY)

Late-Stage Stitching Enabled by Manganese-Catalyzed C-H Activation: Peptide Ligation and Access to Cyclopeptides Sci. Adv. 2021, 7, DOI: 10.1126/sciadv.abe6202.

\title{
Manganese-Catalyzed Late-Stage Functionalization of Peptides
}
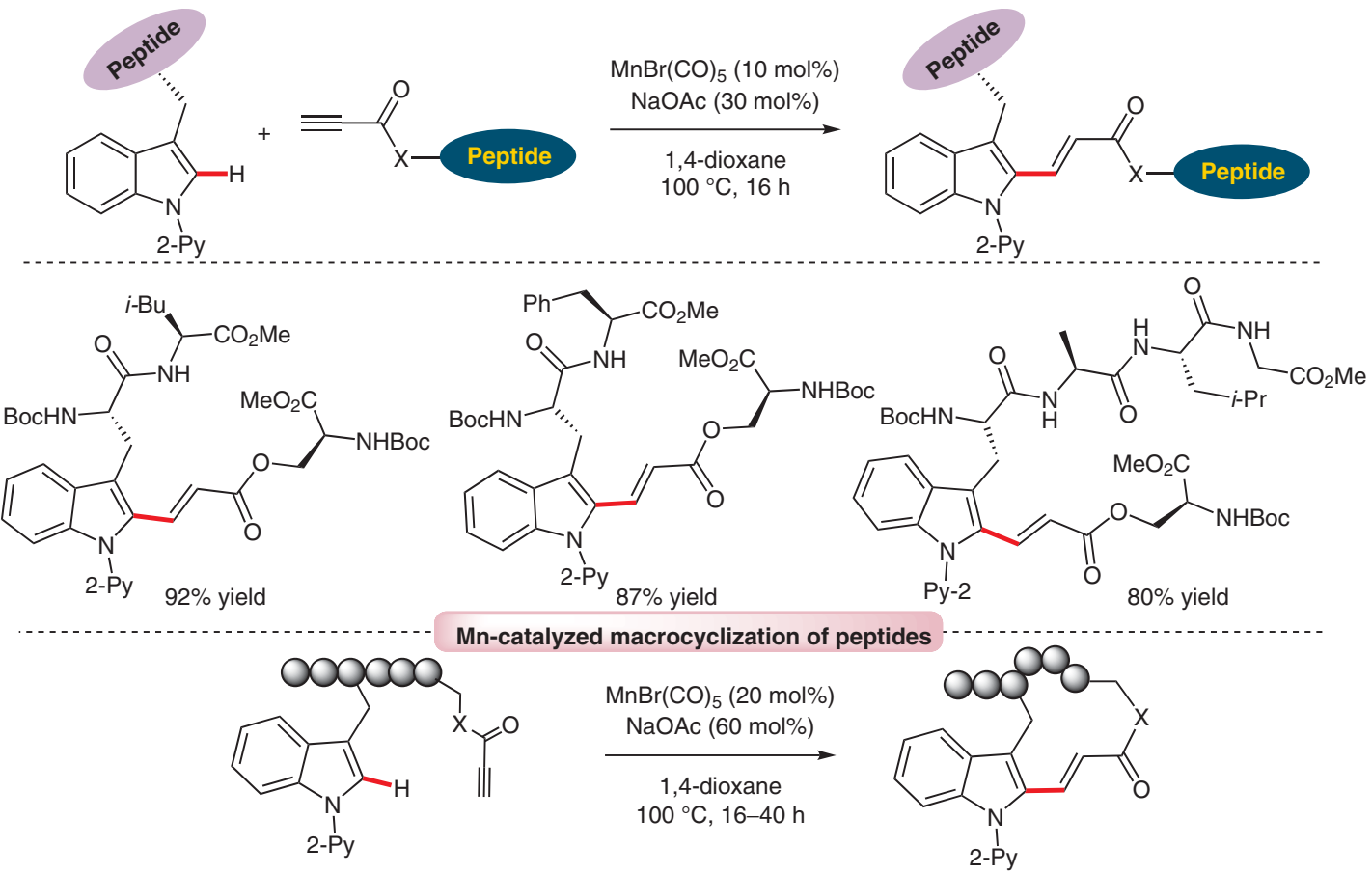

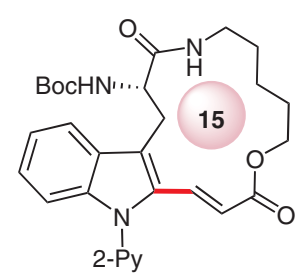

$64 \%$ yield, $E / Z=94: 6$

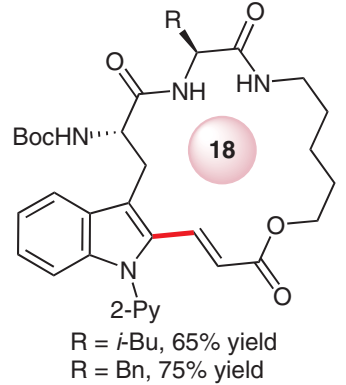

$\mathrm{R}=\mathrm{Bn}, 75 \%$ yield

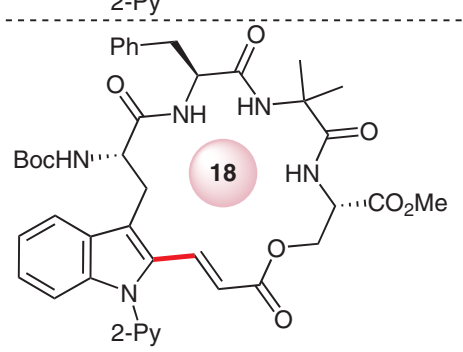

$65 \%$ yield, $E / Z=90: 10$

\section{Category}

Peptide Chemistry

\section{Key words}

late-stage functionalization manganese catalysis macrocyclic peptides

C-H activation

hydroarylation
Significance: Structurally modified complex peptides play an important role in the field of peptidedrug discovery. In this context, a Mn-catalyzed C-H bond-activation strategy has been developed for the synthesis of complex peptides and cyclic peptides.
Comment: The $\mathrm{Mn}(\mathrm{I})$-catalyzed $\mathrm{C}-\mathrm{H}$ hydroarylation of peptides proceeded smoothly to afford structurally complex peptides and macrocyclic peptides in high yields. The reaction shows high chemo- and regioselectivities. 